\title{
SME SECTOR DEVELOPMENT THROUGH FINTECH IN GEORGIA
}

\author{
VAKHTANG CHARAIA \\ PhD in Economics, Associated Professor \\ Business and Technology University, Georgia \\ vakhocharaia@gmail.com
}

\section{MARIAM LASHKHI}

\section{Financial Analyst}

TSU Centre for Analysis and Forecasting, Georgia

mariam.lashkhi09@gmail.com

Abstract. Article analysis new technological opportunities for Georgia to reduce the Small and Medium size Enterprises (SME) financing gap, which hinders not only their own, but country's economic development. While SME sector has a vital role in employment, inclusiveness, gross domestic product generation and etc. in any country in the world and especially in developing ones, they still face significant credit constraints having bank centered, non-diversified financial systems within their economies. However, modern digital financial technologies, could be seen as a paradigm changing instrument for Georgia. The reasons for the Fintech industry at the initial stage of its development in Georgia are different and mainly related toward (but not limited with): not enough legislative support so far; lack of financial education among society and even SME sector; low competition on the market; covid-19 global pandemic and related challenges; not enough motivation among businesses and businessmen to spend enough time, money and effort to innovate; lack of interest from the fintech industry because of small market size and etc.; decrease the foreign direct investments and increase the investment's share in the banking sector and the absence of qualified workforce in needed amount.

KEYWORDS: SMALL AND MEDIUM-SIZED ENTERPRISES, FINTECH, FINANCIAL GAP, ECONOMIC GROWTH.

For citation: Charaia, V., \& Lashkhi, M. (2021). SME Sector Development through Fintech in Georgia. Globalization and Business. 12, 179-185. https://doi.org/10.35945/gb.2021.12.025

\section{INTRODUCTION}

SMEs are recognized to be a crucial part of any economy (Lu, 2018), does not matter it is rich or poor country. They play a critical role in any economy from the prism of: employment, tax revenues to the state budget, inclusiveness, economic diversification, sustainable development and etc. Nevertheless, SMEs encounter tremendous number challenges, it will be legislative, financial, market caused or etc., especially in developing countries as Georgia.

Despite the data fragmentation and differences in methodologies all over the world, it could be concluded that SMEs, as a leading form of enterprise worldwide are accounting for around 99 percent of all firms in the OECD area, providing nearby 70 percent of total employment, 50 percent value creation and 60 percent of all value added on average (OECD, 2016). Although, in emerging economies contributing up to $1 / 2$ of total employment and around 30 percent of GDP (OECD, 2017; G20, 2020).
Despite this significant achievements worldwide, for instance SMEs receive merely 17 percent of bank credits, for instance, in UK, while the rest goes to large corporations (Lu, 2018). The situation is even more problematic in developing countries, where banking regulations hinders SME sector from many different aspects, including: collateral requirements, inability to estimate the business potential outside big cities, extreme price of the loan and etc. (Charaia et al., 2020; 2021). Thus, the vital necessity of alternative financing sources is critical, as never before.

As if they had no more challenges to deal with, small and medium enterprises all over the world, and especially in the developing world was attacked by unprecedented global pandemic of Covid-19, also known as Coronomic Crisis (Papava \& Charaia, 2020; 2021 (a); 2021 (b)). Which brought enormous number of business to collapse or at least to forceful operational stop, especially at the service sector. 


\section{LITERATURE REVIEW}

Considering those existing challenges for SME in the prism of access to finance from the banking sector (GFD, 2017) and systematic regulations toughening by local and international regulators, fintech technologies could be seen as a new breath of fresh air in different regions +(Lukonga, 2018). Berger and Udell (2006) study shows that SMEs cannot usually find the common language with the banking sector because of their: weak transparency, poor financial administration, inability to provide a collateral (in case of Georgia could go as high as 220 percent).

However, only the existence of financial challenges for SME sector is not enough to solve their problems through fintech technologies, since it requires at least a proper ground for its implementation, such as: well developed IT infrastructure, digital skills and financial literately among society, proper legislation for obtaining specific data and etc. However, it is also the fact that the modern digital technologies has a strength to play a key role in the process of sustainable economic development (Turmanidze et al., 2020; Benashvili, 2017).

While observations show that bank loans are still the main source of financing for SME (Schweitzer, Barkley, 2017) and bearing in mind that literature on innovative digital financing is limited (Hua et all, 2019), some studies by this time show, that the awareness on alternative financing through fintech is increasing (Walden, 2020; Harbar, 2021) and the last decade has become an extremely successful (Jaksic \& Marinc, 2019; GII, 2020), making its own input in the fourth industrial revolution (Chang et al., 2020), not without a significant coronomic push.

Rapid fintech popularity growth all over the world could be explained by different reasons (Odinet, 2018), which could be:

- Faster loan processing speed, in comparison to traditional sources (Sangwan et all, 2019);

- Lower operating costs related toward credit management (Ozili, 2018);

- Coziness in credit obtaining procedures, especially in remoted areas with no necessity to travel far distances;

- less bureaucracy from the regulators usually challenging the client - bank relations;

- Opportunity to get a credit with lower interest rate and etc.

At the same time, benefits also go the lenders side:

- It's easier for fintech companies to be backed by investor's and not company's own money (Anagnostopoulos, 2018);

- Diminishing credit risks based on innovative technologies of big data analysis (Lu, 2018);

- Speedily increasing number of clients and financial turnover from the remoted areas unachievable for other lenders.

Most, if not all above mentioned advantages both from the clients and business side, most likely would not be possible to obtain if not the fintech and the modern digital technologies they are using. However, there are risks as well, which requests a top level attention:

- Cybersecurity;

- Online data protection;

- Banking sector's resistance and lobbing against fintech;

- Financial and business illiteracy among the wider population;

- Difficulties with Internet connectivity and usage, especially in rural areas of developing countries.

\section{GLOBAL TRENDS}

As already stated above, because of tightened capital and liquidity regulations from national and sub-national / international regulators, especially after the financial crisis of 2008, banks are encouraged to scrutinize their clients, thus leading toward higher interest rates (Buca \& Vermeulen, 2017). However, SME sector here has been negatively affected more, then by contrast bigger businesses (Yoshino \& Yamagami, 2017). However, the most important and essential fact is that the difference between the developing and developed economies financial systems (which is the banking system in absolute majority cases) is that the first requires such problem causing collateral payment, while in the second case, for instance in Europe SMEs are getting credits lines for their business, which is typically uncollateralized (see Columba et al. 2010 for the Italian case).

There are also important trends which signal positive perspectives for SME financing and that is the ground for fintech development, those are:

- Rising volume of non-cash transactions;

- Growing number of banking account users;

- Step by step adoption of relative legislation;

- Spread the innovative business models and etc. ;

- Implementing the modern standards of accounting;

- Initiatives aiming to eliminating cash from circulation;

- Popularization of modern digital technologies and applications;

- Increasing popularity of online shopping platforms (especially after pandemic).

According to the Capgemini (2020) financial services analysis, during the five years before pandemic (2015 - 2019) the volume of global non-cash transactions increased by more than 60 percent, with optimistic predictions of around 54 percent further increase during the next five years from 2019 to 2023.

\section{CASE OF GEORGIA}

First of all it is important to distinguish what is the SME meaning in local Georgian context, since its understanding could vary from country to county. According to the Georgian National Statistics office understanding: 
- Small business are considered as those with less than 50 employees and/or up to 12 million GEL annual turnover;

- Medium size business employ from 50 to 250 persons and/or have a turnover between 12 and 60 million GEL;

- What is higher, i.e. more than 250 employees and turnover over 60 million GEL represents the big scale business.

However, should be noted that according to the size of

\section{Diagram 1. Different statistics on SME sector in Georgia} Turnover (Billion)



Value Added (Billion)

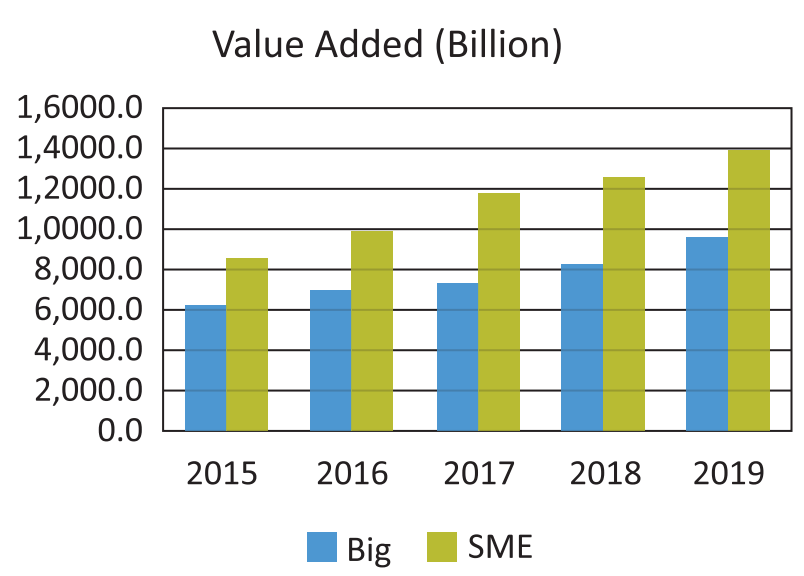

the local economy, these numbers could be exaggerated. For instance if in the USA or Germany, a company with employers number of 45 persons could be counted as a small business, in Georgia such companies are hard to name small. Because of such segmentation the total majority of active companies in Georgia represent SME sector - 99.8\%, while the number of active big companies is only - 300 .

Despite the finance gap equal to $18 \%$ of GDP (SME Finance Forum, 2021) and other type of challenges faced by SME sector in Georgia, they still have significant impact on
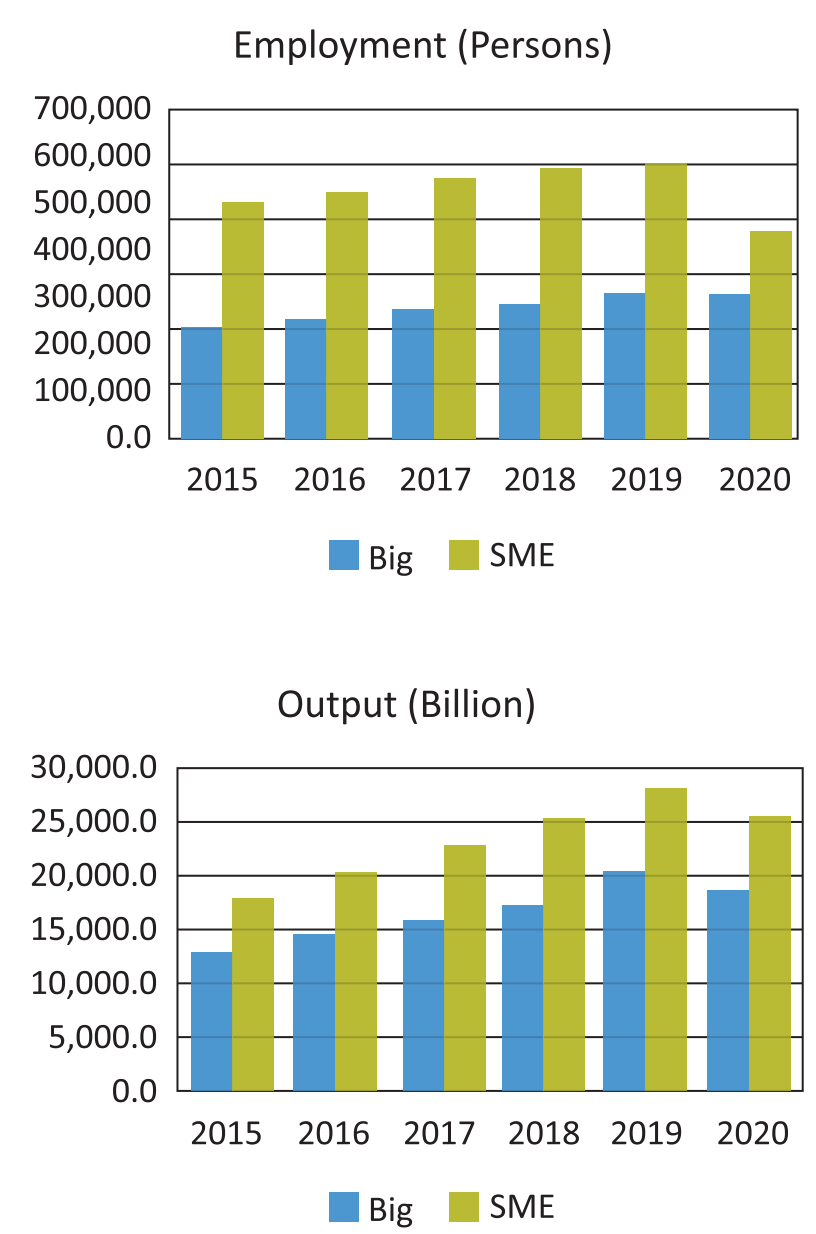

\section{Avarage Salary Per Month}

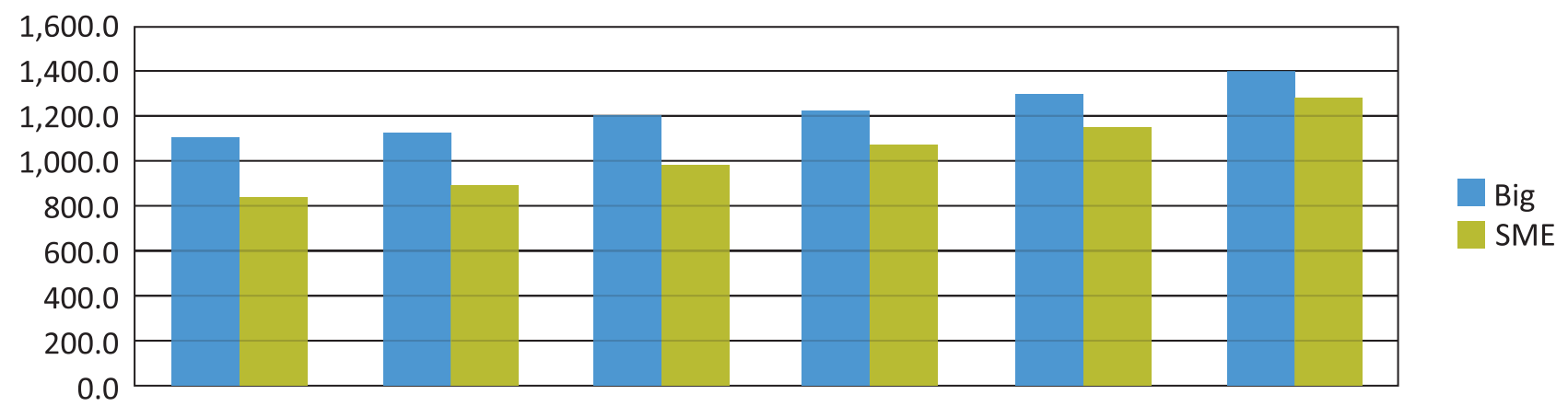

Source: GEOSTAT https://www.geostat.ge/en/modules/categories/195/business-statistics 
Georgian economy and represent (see diagram 1 for more details): a) 41 percent of total turnover, b) 58 percent of employment, c) 59 percent of value added and d) 58 percent of total output. Not speaking about the inclusiveness and diversification they provide to local economy, which can never be achieved by big companies. Even the average salary shows to be almost equal, however taking into account the business models at big companies with many times higher salaries for the top management and significantly lower salaries for the staff, it could be said that SME is not losing even this position to the big businesses.

Historically it has never been so cheap to take a loan from the bank in Georgia, as it is nowadays (diagram 3), if not counting some minor fluctuation because of Covid-19 effect. However, if looking in more details it is in average $15 \%$ interest rate in local and around 7 percent in foreign currencies, which still makes a lot of challenges for local companies. Firstly, because the interest rate on local currency is expensive even without naming other problematic aspects and secondly, because of extremely unstable exchange rate the formal 2.5 times cheaper foreign currency loan could end with more problems even then the loan in local currency.

Theoretically there are different ways how companies could avoid the complicated banking restrictions for obtaining financing, for instance from the capital market. However in developing countries such mechanisms are hard to use, due to different practical challenges in general related toward: trust, transparency, legislation, popularity, attractiveness and etc.

Because of many different reasons it's obvious that fintech will solve several important problems (collateral, geographic proximity, price of loan and etc.) for SME to get financing, but because of even more reasons it's hard to guarantee that only appearance of fintech will solve the problems in this country. The reasons here are too many:

- Not enough legislative support so far;
The national bank of Georgia, which has to take bold steps to create a proper legislative base for alternative financial institutions support is pausing the reform for years already, thus strengthening the banking dominance and consequently postponing the SME sector's sustainable growth at least from the financial point of view. At the same time legislation which should be adopted from the Georgian Parliament's side in many cases is also late (in general it is harmonization with EU standards), hindering immense opportunities for ICT and consequently country's economic development (Margvelashvili, 2020).

- Lack of financial education among society and even SME sector:

Unfortunately, because of wide spread soviet style business making experience, even the business people prefer to act according towards their own intuition, rather than to follow the most advanced business decisions so popular in developed world. This goes even to such simple issues as creating a company and to such important aspects as expansion, where once own knowledge and finances could be inadequate (Bedianashvili, 2018), but in most cases business owners don't want to have partners or investors, not to lose their total "freedom", forgetting about the benefits and advantages new companions can bring to the company. That comes and continues with low financial education along the country, starting from the school pupils (Kvirkvaia, et al, 2018), continuing with youth and adults and finishing with the elders group.

- Low competition on the market;

Because of free market in most directions and only some level of competition in a very few business directions, businesses do don't feel the stress and need for systematic progress, such vitally important for market development.

\section{Diagram 3. Interest Rates on Loans in Georgia (\%)}




Even the banking sector feeling comfortable not to go into competition within each other, but simply to share the market according to the level of their finances and influence.

\section{- Covid-19 global pandemic and related challenges}

From one point of view Covid-19 pandemic should have a positive influence on modern digital technologies popularization and their implementation and the reality because of other side of Covid-19, such as lockdowns, supply chain break downs, chaos on consumer market, socioeconomic instabilities and etc. (Pirveli et al., 2020), has prevented the process for at least some time in the future.

- Not enough motivation among businesses to spend enough time, money and effort to innovate;

According to EBRD and the World Bank Group data, only 2.9 percent of small and 15.2 percent of medium business in Georgia do export their products (OECD, 2016). This is the best illustration of laziness of business sector in Georgia which has a free trade regime almost with the 1/4th of the world population, including EU and China (Shatakishvili, 2021). For comparison reasons, small companies in eastern Europe do export around 5 times more -15 percent of their productions, while medium business exports more than $1 / 4$ th -25.6 percent of their products.

- Lack of interest from fintech industry because of small market size and etc.

Because of small market in general, but also because of other challenges mentioned above, 3.7 million nation with GDP around 17 billion USD seems to be an uninteresting dot for signature players, while smaller players need time to cover the market needs, if at all. Economic partners, such as China, EU and/or US could play a vital role in development not only trade, tourism and investments in Georgia (Charaia \& Lashkhi, 2020; 2021), but to promote a fintech industry as a new perspective direction in their portfolios.

- Decrease of foreign direct investments and increase of investment's share in the banking sector

According to the National Statistics Office of Georgia for last several years in a row the amount of FDI has been decreased for around 3.5 times (2017 year - \$1.98 billion;
2018 - \$1.32 billion; 2019 - \$1.36; 2020 - 0.57 billion), while one of the dominant shares of investments still belongs to the Financial Sector which nowadays is nothing else but the banking sector, which on its turn is oriented not on sustainable economic development, but simply on short term operations such as - import-export operations (Charaia \& Lashkhi, 2018; Sikharulidze \& Charaia, 2018). Consequently, it's especially hard to promote and implement alternative financial instruments, while the dominant position from different perspectives still belongs to the banking sector.

- $\quad$ Absence of qualified workforce in needed amount.

Over those reasons mentioned above from the governmental point and from the business side, there is maybe the most significant part in shortage and that is a qualified labor force. Unfortunately, local market is very scarce in ICT specialists (Ghonyan, 2020), which increases the price and time to get from the market or to create one and also increases the competition to maintain him/her.

\section{CONCLUSION}

At the era of SME sector ascendency all over the world, innovative technics of financing for small and medium companies are also available, but not everywhere and not for everyone. Countries like Georgia significantly depended on workplaces, production, taxes and etc. from the SME business have no time to waste and not start a complex procedure of constructing a full fledge fintech environment, including with all those amendments in legislation, increasing financial literacy among population, supporting growth and attraction of qualified labour force, increasing motivation for making innovative digital businesses and etc.

Georgian economy has to use all its positive achievements and reputation to farther increase its sustainable economic growth perspective. Harmonisation of legislation with EU, creating competitive balance between existing banking sector and the fintech industry, for the sake of advancing local SME sector has a power to advance the whole Georgian economy to the new heights. Challenges on this way are already detected and possible to overcome with proper political and practical will, which should prevail for the ultimate goal of diversified, inclusive and sustainable economic development.

\section{REFERENCES:}

Anagnostopoulos, I. (2018). Fintech and Regtech: Impact on regulators and banks. Journal of Economics and Business, $100,7-25$. Bedianashvili, G. (2018). Knowledge economy, entrepreneurial activity and culture factor in modern conditions of globalization: challenges for Georgia. Journal: Globalization and Business, (5), 32-37. https://doi.org/10.35945/gb.2018.05.004

Benashvili, G. (2017). Boosting Entrepreneurship in Georgia Development of Fab Labs. PressAcademia Procedia 4, (1), $29-33$. Berger, A.N., \& Udell, G.F. (2006). A more complete conceptual framework for SME finance. J. Bank. Financ. 30 (11). 
Bucă, A., \& Vermeulen, P. (2017). Corporate Investment and bank-dependent borrowers during the recent financial crisis. Journal of Banking and Finance 78 (C), 164-180.

Chang, V., Baudier, P., Zhang, H., Xu, Q., Zhang, J., \& Arami, M. (2020). How Blockchain can impact financial services - The overview, challenges and recommendations from expert interviewees. Tech. Forecast. Soc. Cha 158.

Charaia, V., Chochia A., \& Lashkhi M. (2020). The impact of FDI on Economic development: The Case of Georgia. TalTech Journal of European Studies, 10(2), 96-116. https://sciendo.com/article/10.1515/bjes-2020-0017.

Charaia, V., Chochia A., \& Lashkhi M. (2021). Promoting Fintech financing for SME in S. Caucasian and Baltic States during the Covid-19 Global Pandemic. Journal of Business Management and Economics Engineering, 19 (2).

Charaia, V., \& Lashkhi M. (2018). An analysis of the motives underlying foreign direct investments (the case of Georgia). Central Asia \& the Caucasus, 19(4). https://www.ca-c.org/online/2018/journal_eng/cac-04/07.shtml

Charaia, V., \& Lashkhi M. (2020). Georgia and China: The Economic Ties that Could One Day Bind. A Sea Change?: China's Role in the Black Sea, 26. https://mei.edu/sites/default/files/2020-11/A\%20Sea\%20Change\%3F-China\%27s\%20Role\%20in\%20 the\%20Black\%20Sea.pdf

Charaia, V., \& Lashkhi M. (2021). Strategic cooperation between China and the South Caucasus countries. China and Eurasia: Rethinking Cooperation and Contradictions in the Era of Changing World Order. Routledge. https://www.taylorfrancis.com/ chapters/edit/10.4324/9781003109259-14/strategic-cooperation-china-south-caucasus-countries-vakhtang-charaiamariam-lashkhi

G20. (2020). Promoting Digital and Innovative SME financing. https://www.gpfi.org/sites/gpfi/files/saudi_digitalSME.pdf

Geostat. (2021). Business Statistics. https://www.geostat.ge/en/modules/categories/195/business-statistics

Geostat. (2021). Foreign Direct Investments. https://www.geostat.ge/en/modules/categories/191/foreign-direct-investments Ghonyan, L. (2020). E-Commerce, Opportunities and Challenges: Prospectus for Developing Countries. Opportunities and Challenges: Prospectus for Developing Countries.

Global Findex database. (2017). MSME Finance Gap Database. http://smefinanceforum.org/sites/default/files/MSME\%20 Finance\%20Gap\%202018-19\%20Update\%20(public)\%20.xlsx

Hua, X., Huang, Y., \& Zheng, Y. (2019). Current practices, new insights, and emerging trends of financial technologies. Industrial Management \& Data Systems.

Jaksic, M., \& Marinc, M. (2019). Relationship banking and information technology: the role of artificial intelligence and fintech. Risk Manag. 21 (1), 1-18.

Kvirkvaia, M., Kikutadze, V., Sikharulidze, D., Shaburishvili, S., \& Charaia, V. (2018). Study of factors affecting young people's professional orientation in Georgia,' Globalization \& Business, 233-242.

Lu, L. (2018). Promoting SME finance in the context of the fintech revolution: A case study of the UK's practice and regulation. Banking and Finance Law Review, 317-343.

Lukonga, M. I. (2018). Fintech, Inclusive Growth and Cyber Risks: Focus on the MENAP and CCA Regions.

Margvelashvili, T. (2020). Fostering E-Commerce in the Light of the Deep and Comprehensive Free Trade Area (DCFTA): A Case Study of Georgia. J. Law, 122.

National Bank of Georgia. (2021). Interest Rates on Loans, by Quarters and Years. https://nbg.gov.ge/fm/\%E1\%83\%A1\%E1\%8 3\%A2\%E1\%83\%90\%E1\%83\%A2\%E1\%83\%98\%E1\%83\%A1\%E1\%83\%A2\%E1\%83\%98\%E1\%83\%99\%E1\%83\%90/loans/eng/ annual-weighted-loans-interest-rates-Iwireng.xlsx?v=z2rpq

Odinet, C. K. (2017). Consumer Bitcredit and Fintech Lending. Ala. L. Rev., 69, 781.

OECD. (2016). Entrepreneurship at a Glance 2016, OECD Publishing, Paris. http://www.worldsmeforum.org/wp-content/ uploads/2016/10/EntrepreneurshipataGlance.pdf

OECD. (2016). Recommendations for Georgia's SME Development Strategy 2016-2020. https://www.oecd.org/eurasia/ competitiveness-programme/eastern-partners/Recommendations_for_Georgia_SME_strategy.pdf

OECD. (2017). Meeting of the OECD Council at Ministerial Level. OECD Publishing, June 7-8. Paris. https://www.oecd.org/ industry/C-MIN-2017-8-EN.pdf

Ozili, P. K. (2018). Impact of digital finance on financial inclusion and stability. Borsa Istanbul Review, 18(4), 329-340.

Papava, V., \& Charaia V. (2020). The coronomic crisis and some challenges for the Georgian economy. GFSIS, Expert Opinion, (136). https://www.gfsis.org/files/library/opinion-papers/136-expert-opinion-eng.pdf

Papava, V., \& Charaia V. (2021 a). Public Debt Increase Challenge under COVID-19 Pandemic Economic Crisis in the Caucasian Countries. Journal of Contemporary Issues in Business and Government. 2021, 27(3). https://cibg.org.au/article_10671.html.

Papava, V., \& Charaia V. (2021 b). The Problem of the Growth of Georgia's Public Debt during the Economic Crisis under the COVID-19 Pandemic. GFSIS, Expert Opinion, (152). https://www.gfsis.org/files/library/opinion-papers/152-expert-opinion-eng.pdf

Pirveli, E., Shugliashvili T., \& Machavariani N. (2020). Rethinking economic policy of Georgia in the times of COVID-19. International Journal of Economic Policy in Emerging Economies.

Sangwan, V., Prakash, P., \& Singh, S. (2019). Financial technology: a review of extant literature. Studies in Economics and Finance. Schweitzer, M. E., \& Barkley B. (2017). Is "fintech" good for small business borrowers? Impacts on firm growth and customer satisfaction. Federal Reserve Bank of Cleveland Working Paper.1. 
Shatakishvili, D. (2021). Economic Ties of Georgia with Central Asian Countries and Future Cooperation Perspectives. International Journal of Trend in Scientific Research and Development. 5, (6), 305-314. www.ijtsrd.com/papers/ijtsrd46396.pdf

Sikharulidze, D., \& Charaia V. (2018). Oli paradigm and investment position of Georgia. Globalization \& Business. 71-78. https://www.eugb.ge/view_archive2.php?content=content\&id=126\&OLI\%20PARADIGM\%20AND\%20INVESTMENT\%20 POSITION\%200F\%20GEORGIA

SME Finance Forum. (2021). MSME Finance Gap. https://www.smefinanceforum.org/data-sites/msme-finance-gap

Turmanidze, R., Dašić, P. \& Popkhadze, G. (2020). Digital infrastructure in Georgia as a condition for successful application Industry 4.0. Industry 4.0, 5(1), 3-6.

Walden, S. (2020). What Is Fintech And How Does It Affect How I Bank? Forbce. https://www.forbes.com/advisor/banking/ what-is-fintech/\#: :text=Fintech\%20refers\%20to\%20software\%2C\%20algorithms,reality\%20(VR)\%20trading\%20 platforms.\&text=The\%20annual\%20Forbes\%20Fintech\%2050,on\%20the\%20market\%20worth\%20noting.

Yoshino, N., \& Yamagami, H. (2017). Monetary Economics: Practice and Theory. Keio University Press.

Harbar, Z., \& Harbar, V. (2021). Fintech as a modern form of financing. Scientific letters of academic society of Michal Baludansky. 9, (1), 44-47. 